\title{
5. Samoa: The Observer and threats to media freedom
}

\section{COMMISNIARY}

Media freedom is not absolute, which is why we also accept that laws must be instituted, to prevent and discourage media owners, editors and journalists from abusing this freedom. The problem, however, is that, whereas these laws are made by politicians to protect themselves and members of the public from a critical media, there are no laws to protect media owners, editors and journalists from angry politicians.

\section{SAVEA SANO MALIFA}

Publisher, Samoa Observer, Apia

7 HE SAMOA OBSERVER was founded in a cookhouse in a village near Apia in August 1978. Almost right away it struck problems. The

government of Prime Minister Tupuola Efi did not like the idea of this new newspaper publicly revealing all these things that had never been revealed before. But Tupuola was an understanding man and very tolerant too. It was his cabinet ministers who were doing things they shouldn't be-and Tupuola got the blame. He is now Samoa's Head of State, and his name has changed to Tui Atua Tupua Tamasese Efi.

When the paper completed its first year of operation, and we were planning its first birthday party, we invited Tupuola to deliver the keynote address. At first he was reluctant, but he later accepted.

This is what he said:

I suppose I can get away by saying: 'Happy birthday and I wish you well.' I would like to say a little more.

The Observer was launched one year ago by way of indulging the (whims) of a somewhat querulous reporter who believed that he could do it better on his own.

It was a brave effort because striking out on newspaper business in Apia has not by and large brought good fortune, let alone spiritual and mental fulfillment. There was a tendency, therefore, for people to 
say when the first issue appeared on the streets of Apia: 'Very good for a start but can the effort be sustained? One year later I will have to acknowledge, even if a little grudgingly, that the Observer has become an established feature of the Apia scenery.

Tupuola goes on:

It is, one year later, better patronised by business and even by patrons, who ironically, the Observer spends most of its time rubbishing. The last reason why I say it is heading happily towards the status of a survivor is that the editor seems, again on the face of it, well able to indulge his idiosyncrasies, even to the point where he feels he can thumb his nose at politicians, bureaucrats, their values and their cocktail parties, and still manage to retain his contacts, 'deep throat' and all.

And he ends:

Nevertheless, I look forward to another year of being, on turns, lifted, prodded, annoyed, misrepresented - which reminds me that the headings 'PM wants CJ out' and 'Appealing to PM is time wasting' do not represent fair reporting.

With all that, I hasten to say, I wish the Observer many happy birthdays.

\section{Long confrontation}

That was in August 1979. Two years later, public servants went on strike seeking better wages, but Tupuola did not grant the request. He believed the opposition Human Rights Protection Party (HRPP) was behind the strike so he refused to listen. As a result, the confrontation dragged on for 13 weeks, which was when the HRPP launched a vote of no confidence against Tupuola in Parliament. The vote was carried and Tupuola was no longer PM.

The HRPP became the new government, and some years later the Observer struck worse problems. They included threats to kill from a cabinet minister, physical assault by the minister's brothers, a 'suspicious fire' that completely destroyed the paper's printing plant, web presses and newsprint supplies, editorial and adverting offices.

Soon afterwards the lawsuits from the PM and his cabinet ministers began, all because of our love of press freedom and freedom of information in the Pacific. But then these are the things that all of us who work as journalists in this part of the world, know very much about. 
They've been around us for a long time, and I don't think they are going to go away any time soon. I say this because as long as our politicians refuse to totally accept, and respect, modern-day democracy, these threats are going to remain with us for some time yet.

We know and accept that like any other freedom, media freedom is not absolute, which is why we also accept that laws must be instituted, to prevent and discourage media owners, editors and journalists from abusing this freedom.

\section{Quick to sue}

The problem however is that while these laws are made by politicians to protect themselves, and members of the public from a critical media, there are no laws to protect media owners, editors and journalists from angry politicians. Besides, whereas politicians are quick to sue editors-saying they've been defamed by them-all that editors can ever do in response is try to defend themselves.

To get an idea as to why these threats from politicians are continuing to be a tenacious enemy of media freedom and the free flow of information, we have to go way back to those pre-independence days when modern democracy was unheard of in our part of the world.

In those days, all island nations had their own forms of democracy, driven by their respective cultures and inherent customs. In Samoa for instance, preindependence democracy was dictated by the fa' a samoa or the Samoan way of life, which was where the matai, or chief of the family, made all the decisions.

The reasoning though is sound enough. Since the matai is chosen unanimously by the extended family, based on his ability to adequately provide for that family, and for his kindness and his wisdom, his decisions are also the rules by which the family is governed in peace and unity. In other words, the matai is respected and his decisions are obeyed without question.

Then, on 1 January 1962 along came political independence accompanied by modern democracy, and everything changed. We are now driven by foreign-influenced constitutions that emphasise alien concepts such as human rights, freedom of expression, freedom of the press, freedom of religion, and so on. While these are inalienable human values, they also diminish the matai's culturally-inherited authority, since under this new form of governance, the non-matai is now just as human and important as the matai himself. Modern democracy becomes a threat to the old system, and it is now looked upon with scepticism and even contempt. 
In Samoan politics, what is important is that most of the Members of Parliament are matai. Of its 49 MPs, 47 are matai, and the other two are elected from the 'individual voters' group or those with mixed ancestry. This means the laws Parliament makes are predominantly made by matai, since they make up the majority in the House.

And since matai are so used to being obeyed without question by their families, they think of their roles in Parliament as extensions of their family and village roles. Likewise as politicians, they also do not want their decisions questioned, especially by the media which to them is a foreign institution that is both irrelevant and potentially dangerous.

\section{Common good}

And that is where problems start. What they have to accept though is that as their countries' political leaders, they are now occupying much more responsible positions where the whole country - not just their immediate families - is dependent on them. Which means that this time, they have no option but to give up their personal ambitions and devote more of their energies into working together for the common good, not just for that of their own families.

They also have to realise that despite their differing views, both the government and the opposition must sit down in a compromising way and work together to solve tough problems, in order to arrive at meaningful solutions that benefit everyone.

They have to agree that although compromise may sound bad, it is essentially good because through compromise great achievements are possible. And yet so far, that is not working in some parliaments of the Pacific. There is still senseless bickering between the government and the opposition, so that basic public services such education, health, electricity, roads, living conditions in the villages, are in general very much substandard.

In Samoa, where the Constitution can be changed by a two-thirds majority of Parliament, the government has been holding defiantly onto that majority over the last 20 years by using public resources under its control to achieve that purpose, so that compromise has been impossible and even negligible.

Which means that while the government has been enjoying that majority, it has also felt quite free to change the Constitution to maintain its supremacy, while at the same time making new laws, one of which amounts to a deliberate threat to media freedom and freedom of information. 
Called the Printers and Publishers Act 1992, this law directs publishers and editors to reveal their sources of information to government leaders such as Prime Minister, cabinet ministers, MPs, and heads of government departments, who claim they have been defamed by the media, mainly newspapers.

Previously, however, only the court had the authority to do this. Although other democratic countries have laws similar to this one, we believe they do not have this particular requirement in them. So that when the Publishers and Printers Act was passed, Samoa ceased to be democratic in the modern sense of the word.

\section{Printers and Publishers Act frightens sources}

Since it seems clear this law was designed to frighten sources from revealing information about political corruption to the media, it effectively undermines media freedom and freedom of information. What's interesting though is that only newspapers are singled out as targets of this law, not TV and radio. Why? We don't know.

When the Publishers and Printers Act was passed, however, a lawsuit by Prime Minister Tofilau Eti Alesana against the Samoa Observer, claiming he had been defamed by it, was already with the court. It was a private claim. And yet in Parliament, an amount of $\$ 783,000$ was proposed and approved to pay for the Prime Minister's legal fees. Later, another amount of $\$ 400,000$ was also approved for the same purpose since the first one was not enough.

And, as if to justify using public funds to pay for the Prime Minister's legal fees, the government announced inside Parliament that all the legal fees to be incurred by public figures who pursue defamation claims against newspapers, would also be paid for by public funds. Meantime, the newspaper has had to pay its own legal fees amounting to hundreds of thousands of Samoaan tala.

Now the question arises: Is that a threat to press freedom and freedom of information?

Anyway that was in May 1998. And only one man stood up in Parliament when those funds were approved and said yes, that it was not only a threat to press freedom, but a breach of press freedom and freedom of information as well.

That man was the Leader of the Opposition, Tuiatua Tupua Tamasese. He told Parliament: 'This decision breaches freedom of speech guaranteed in the Constitution. The Prime Minister does not worry about money because the 
government is paying. However, the Observer is bound to be hurt financially whether it wins or not, since it is paying for its own legal fees. And if this is what will be happening to newspapers, their freedom to express themselves as required by the Constitution cannot be protected.'

\section{Many lawsuits}

Tuiatua added: 'The Prime Minister and other government officials will keep on suing them for defamation knowing well they do not have to part with a cent of their own.'

Tuiatua was right. Soon afterwards, the Prime Minister sued the paper again, and so did two of his cabinet ministers, all at about the same time. This time they sought between $\$ 200,000$ and $\$ 250,000$ in damages.

However almost two years later, the Prime Minister and one of the ministers withdrew their lawsuits without explanation. In other words, their intentions were to intimidate, frighten, and discourage alleged government corruption from being exposed. And the third plaintiff, his own claim still in court, was jailed in 1999 for plotting the murder of another cabinet minister. He is still in jail today.

But then, as if that was not enough, the Prime Minister later used the British law of criminal libel which carries the penalty of six months in jail against the Observer. And yet it was an ancient law meant to quell rebellion and treason in Britain's colonies around the world. We believe that New Zealand, Canada or Australia do not have this law in their law books. However, it was being used in Samoa in an attempt to put the editor behind bars.

And so, as we can now see, governments in the Pacific are quite capable of using any old law to stifle press freedom and freedom of information in their countries. In Samoa, not only is the government constitutionally able to make any new law it wants, it is also financially able to use foreign lawyers and judges to carry out its desires legally.

In the case of the late Prime Minister suing the newspaper for defamation a few times, his legal fees were paid for by public taxes, as were the expenses of lawyers from aboard he had hired to represent him, as well as for the expenses of the judges who presided in those cases.

\section{Troubling admission}

At the start of the Prime Minister's defamation action against the Observer 
in 1998, he declined to give evidence. In response, Mr Justice Bisson, a New Zealander, admitted this was the first time in his knowledge that a plaintiff suing for defamation had refused to appear in court to explain how he had been defamed. It was a troubling admission but then he allowed the trial to go ahead anyway.

Later, when Mr Justice Bisson delivered his judgment on 16 September 1998, he said he did not take into account that the Prime Minister's case was being funded by the Samoan government. He then denied the Prime Minister's full claim of $\$ 600,000$ for his legal costs and awarded just $\$ 75,000$ instead.

And on the Prime Minister's claim of damages for $\$ 400,000$, Bisson said he took into account that the plaintiff was only 12.5 percent successful, and awarded him $\$ 50,000$. What about the other 87.5 percent? Isn't defamation either 100 percent successful or there is no defamation at all? Anyway, by then the government - with Parliament's endorsement - had \$1.18 million allocated for the Prime Minister's legal costs and legal fees.

And then on 3 October 1998, a notice seeking payment of a total of $\$ 125,000$ in judgment and costs awarded to the Prime Minister was filed in the Supreme Court. It said the full amount must be paid within three weeks or the plaintiff 'will petition the Supreme Court for an order to wind up the Samoa Observer Company Limited'.

Two days later, another notice was received saying an 'interest of 8 percent per annum' had been added. It also said failure to comply could lead to 'bankruptcy proceedings taken against you'.

By this time, the manner in which these legal proceedings had been handled clearly showed it was an attempt to bankrupt the newspaper. First, the Prime Minister sued for defamation, then he arranged for an overseas Queen's Counsel to defend him, later the government hired an overseas judge to hear the case, and then armed with its two thirds majority in Parliament, the government got that substantial sum of money approved for the PM's legal fees Later when the hearing began, the Prime Minister refused to give evidence, and yet he was supposed to explain how he had been defamed, which was also when he would have to be cross-examined. The judge appeared shocked but he allowed the trial to go ahead anyway. Afterwards when he delivered his ruling, he said: 'Had the Prime Minister elected to open and give evidence in the usual way in support of his case, there would have been a substantial saving in time and expense'. 


\section{Criminal libel}

At the time however, the Prime Minister's claim of criminal libel was still pending. And then he passed away and everything changed. The court matters - including the criminal libel charge - were discontinued, the threat to institute bankruptcy proceedings was not heard of again. Life returned to near normal. But did the Prime Minister have to die for justice to be finally made? And did the threats to media freedom and freedom of information in the Pacific stop then?

No, they did not. A few years ago in Honiara, Solomon Islands, editor the Rev John Lamani was in his Solomon Star newspaper office when armed soldiers - or were they police officers? - walked inside, and at gunpoint, demanded that he hand over a large sum of money; they then revealed their orders were from a cabinet minister. Later the money was handed over.

Just over a year ago in Suva, Fiji Sun editor Russell Hunter was woken up in the middle of the night by soldiers. They said he was wanted at Suva's Queen Victoria Military Barracks for questioning, and he was taken away by force. Back in his house, his frightened wife and their young daughters remained in confusion, not knowing what was happening. But then instead of taking him to the Suva barracks, Hunter was driven across the country to Nadi where he was led inside a passenger aircraft and deported to Australia. Hunter is now working for the Samoa Observer as its development editor.

And then you ask: What kind of people would do this sort of thing as if it was quite normal? Don't they have families of their own, wives, children? Sad to say, we're living in what has been lovingly described as a free and peaceful Pacific, and yet where is that freedom and that peace?

Samoa is not free. Despite glowing reports that it is free, deep inside it is not. It is a country sobbing day and night under the weight of suppressed freedom. Even the Church, which is supposed to be the pinnacle of freedom, is not free. Perhaps those church leaders who are so involved in politics should become politicians themselves, and let the rest go free.

Fiji, similarly, is far from free. Voreqe Bainimarama talks freedom but acts suffering. He wants corruption cleaned up, but then he also wants the media shackled, so that they are unable to do the cleaning up. Solomon Islands is not free, nor is Papua New Guinea, despite what their government supporters are saying. The only freedom in the Pacific is poverty. How then can the media be free in a place where there is no freedom? 


\section{Dictator accusation}

Today, it is interesting to see that Samoa's current Prime Minister, Tuilaepa Sailele Malielegaoi, is having a go at Fiji's strongman Bainimarama, accusing him of being a dictator. He is troubled that Bainimarama has recently announced the introduction of a decree to control the Fijian media, and another one to legally protect him and his soldiers-in case they are accused of wrongdoing.

Now Tuilaepa, who has been looking for ways over recent weeks to attack Bainimarama for reasons we are not sure about, simply could not hold back.

'If anything,' he said, 'the decrees are an admission of guilt. They cannot face the consequences of what they've done to their country, so they cloak themselves in immunity decrees.' He advised that 'democratic governments that want to tackle institutional corruption need a free, strong and robust media'.

Now that sounds good to the ear.

And he went on: 'You know, Bainimarama's regime came to power to address presumed corruption in government. So if anything, they should strengthen the media, and give them the freedom to do their work. Not try to strangle them to death.'

\section{Words into action}

Wonderful! And so, perhaps Tuilaepa should now turn those words of his into action, and remove all the restrictive policies threatening to stifle media freedom and freedom of information in his own country, Samoa. He can start by repealing the Publishers and Printers Act 1992, declare defunct the policy allowing public funds to be used for the legal fees incurred by government leaders suing newspapers for defamation, and throw out the ancient British law of criminal libel from Samoa's law books. That would be a big improvement.

And then, to really convince us he intends to make Samoa's media 'free, strong and robust' so that they can help him and his government 'tackle institutional corruption', all he has to do is introduce an Official Information Act in his country. That will surely endear him to the leaders of the free world who are just tired of having to deal with small time dictators, and only then can he successfully achieve what he is striving so hard for.

And when all that is done, he can sit down then and tell himself that unlike Voreqe Bainimarama, he has noble ideals driving him 


\section{MEDIA FREEDOM IN OCEANIA}

forward. That way, media freedom and freedom of information in the Pacific is finally assured, and he is the man who has made that happen. But today, celebrating World Press Freedom Day one more time reassures us that we all need media freedom. In a world where political wars are continuing to gobble up the world's resources, many developing countries are impoverished, so that people dying there from starvation and malnutrition is commonplace. And as brutal dictatorships are causing many to suffer in silence, so that they are deprived of their pride and dignity, media freedom should remain the sustaining lifeblood of democracy.

Therefore as journalists, we should never neglect our role as watchdogs of our governments, since the moment we do, the little freedom we're enjoying today is likely to be taken away from us.

Savea Sano Malifa is publisher and editor-in-chief of the Samoa Observer. He gave an earlier version of this address at the UNESCO World Press Freedom Day Conference at the University of Queensland, Brisbane, 1-3 May 2010 as part of a 'Media freedom in the Pacific' panel. sanomalifa@yahoo.com 
Copyright of Pacific Journalism Review is the property of Auckland University of Technology and its content may not be copied or emailed to multiple sites or posted to a listserv without the copyright holder's express written permission. However, users may print, download, or email articles for individual use.

http://www.aut.ac.nz/depts/commstud/journ/pjrsubs.shtml 